\title{
PROSOCIALAUS IR ANTISOCIALAUS ELGESIO SKALĖS BEI JAUNIMO VERTYBIŲ SPORTINĖJE VEIKLOJE KLAUSIMYNO ADAPTAVIMAS LIETUVIAMS
}

\author{
Saulius Šukys \\ Lietuvos kūno kultūros akademija, Kaunas, Lietuva
}

\begin{abstract}
Saulius Šukys. Socialinių mokslų daktaras. Lietuvos kūno kultūros akademijos Socialinių ir humanitarinių mokslų katedros docentas. Mokslinių tyrimų kryptis - dorovinių vertybių ugdymas sportinėje veikloje.
\end{abstract}

\section{SANTRAUKA}

Tyrimu siekta aprašyti prosocialaus bei antisocialaus elgesio ir jaunimo vertybiu sportineje veikloje instrumentu adaptavimo etapus, ju tinkamuma ivertinant bandomиоји tyrimu. Tyrimo instrumentu adaptavimas lietuviams ir ju patikimumo patikrinimas vykdytas keturiais etapais. Per pirmq etapq atliktas Prosocialaus ir antisocialaus elgesio sportineje veikloje skalès ir Jaunimo vertybiu sportineje veikloje klausimyno vertimas. Per antra etapq atliktas bandomasis tyrimas apklausiant 170 (32 merginos ir 138 vaikinai) sportuojančiu studentu. Trečio etapo metu išskirti faktoriai ir ivertintas ju atitikimas autoriu nurodytiems. Per ketvirta - patikrintas adaptuojamos skales ir klausimyno patikimumas.

Taikant tiriamosios faktoriu analizès matematini modeli buvo ǐskirti keturi Prosocialaus ir antisocialaus elgesio skalès faktoriai, kurie atitiko autoriu nurodytus. Nustatytas prosocialaus ir antisocialaus elgesio skaliu tinkamas vidinis suderinamumas (nио 0,79 iki 0,85), silpnas ryšys tarp sportininku prosocialaus elgesio su komanda ir varžovais ( $r=$ $0,29 ; p<0,01)$ bei tarp sportininku antisocialaus elgesio su komanda ir varžovais $(r=0,31 ; p<0,01)$. Vertinant Jaunimo vertybiu sportinèje veikloje klausimynq ǐsskirtos trys vertybiu grupès: moralinès, gebèjimu ugdymo ir statuso vertybès. Visu triju vertybiu skaliu vidinis suderinamumas yra geras (nuo 0,70 iki 0,85). Nustatytas vidutinio stiprumo koreliacinis ryšys tarp gebëjimu ugdymo ir moraliniu vertybiu $(r=0,47 ; p<0,01)$, gebejjimu ugdymo ir statuso vertybiu $(r=0,50 ; p<0,01)$.

Nustatytas koreliacinis ryšys tarp moraliniu vertybiu ir prosocialaus elgesio tiek su komandos draugais $(r=0,34$; $p<0,01)$, tiek su varžovais ( $r=0,30 ; p<0,01)$ bei neigiamas ryšys su negarbingu sportininku elgesiu su varžovais $(r=-0,29 ; p<0,01)$.

Tyrimo metu išskirtu faktoriu, kurie sutampa su autoriu nurodytais, bei prielaidu apie vertybiu ir elgesio sportinèje veikloje sasaja patvirtinimas, geri vidinio skaliu suderinamumo balai leidžia kalbèti apie adaptuotu tyrimo instrumentu atitikimq validumo ir patikimumo reikalavimams.

Raktažodžiai: prosocialus ir antisocialus elgesys, vertybès sportineje veikloje, tyrimo instrumentu adaptavimas, patikimumas ir validumas.

\section{IVADAS}

$\mathrm{M}$ okslininkai seniai diskutuoja sportininku ugdymo ir jų elgesio sportinèje veikloje tyrimo klausimais (Jones, McNamee, 2000). Antai prieš dešimt metų B. J. Bredemeier ir D. L. Shields (1998) iškèlè tokị klausimą: tiriant dorą sportininkų elgesị ir jị lemiančius veiksnius sportinejje veikloje labai svarbu turèti patikimus ir validžius tyrimo instrumentus. Nors tiek anksčiau, tiek per pastaraji dešimtmetị užsienyje ir Lietuvoje atlikta nemažai tyrimų šioje srityje, tačiau, kai kurių mokslininkų (Kavussanu, Boardley, 2009) teigimu, jų vis dar stokojama. Pažymėtina, kad tiriant sportininkų elgesį sportinès veiklos požiūriu taikyti îvairūs tyrimo metodai ir instrumentai. Pavyzdžiui, pateikiamos įvairios hipotetinès situacijos, kurių metu aprašytas konkretus elgesys 
ir analizuojama sportininku elgesio sprendimai, ketinimai elgtis bei konkretus elgesys (Bredemeier, Shields, 2001; Kavussanu, Roberts, 2001; Kavussanu, Ntoumanis, 2003). Taikytas ir stebèjimas, kurio metu analizuotos sąsajos tarp treneriu ir sportininkų elgesio (VaezMousavi, Shojaei, 2005 a; Arthur-Banning et al., 2009; Vargas-Tonsing, 2009), domètasi agresijos raiška rungtyniu metu (VaezMousavi, Shojaei, 2005 a, b).

Minètos hipotetinès situacijos, nors ir pakartoja realias rungtynių situacijas, yra specifinès tam tikrai sporto šakai ir neleidžia ne tik ivvertinti platesnio elgesio spektro, bet ir palyginti duomenis pagal sporto šakas (Kavussanu, Boardley, 2009). Čia galima paminèti J. Vallerand ir bendraautorių (1997) sukurtą daugiamatę elgesio sportinejje veikloje skalę, kuri vis tik labiau orientuota i garbingą sportininku elgesi. Analogiškai paminètina D. Shields ir kt. (2007) naudota sportininkų elgesio tyrimo skale, kuri per mažai dèmesio skiria sportininkų elgesiui su kitais komandos draugais. Tyrimai rodo, kad komandos draugų elgesys turi itakos tiek individualaus sportininko elgesiui, tiek bendrai komandos moralinei atmosferai (Kavussanu, 2006; Shields et al., 2007). Todèl analizuojant sportininkų elgesi svarbu ivvertinti ir jų tarpusavio bendravima. Kalbant apie stebèjimą paminètina, kad ji vykdyti ne visada paprasta dèl keleto priežasčių: reikalinga speciali įranga, ne visada pakanka vieno tyrejjo, kyla keblumų įvertinant tyrimo duomenu patikimumą ir validumą.

Išsakyti teiginiai skatina mokslininkus kurti naujus tyrimo instrumentus. Paminètina M. Kavussanu ir I. D. Boardley (2009) mokslo bendruomenei pasiūlyta Prosocialaus ir antisocialaus elgesio sportineje veikloje skale (The Prosocial and Antisocial Behavior in Sport Scale). Kurdami šią skalę mokslininkai kèle tikslą pateikti platesni sportininkų teigiamo ir neigiamo elgesio spektrą. Pažymètina, kad remdamiesi A. Banduros dviejų moralès dimensijų teorija autoriai vartoja prosocialaus ir antisocialaus elgesio sąvokas. Prosocialus elgesys apibūdinamas kaip savanoriška pagalba, naudos suteikimas kitiems (Barr, Higgins-D‘Alessandro, 2007), antisocialus - savanoriški veiksmai, kuriais padaroma skriauda kitiems. Minimoje skaleje matuojamos dvi prosocialaus (prosocialus elgesys su komandos draugais ir varžovais) ir dvi antisocialaus (antisocialus elgesys su komandos draugais ir varžovais) elgesio formos.

Ivertinus Lietuvoje atliktus sportuojančių vaikų ir jaunimo elgesio ypatumų tyrimus paminètini tik keli, kurių metu analizuoti sportuojančių paauglių socialiniai igūdžiai (Malinauskas, Šniras, 2006), patyčių raiška (Šukys, Jankauskienė, 2008), požiūris į kilnų elgesį ir jo raišką sportinejje veikloje (Adaškevičienè, Budreikaite, 2007), sportuojančių studentų nuostatos dèl sportinès veiklos dalyviu elgesio (Šukys, 2008). Šie tyrimai yra pakankamai skirtingi keliamais tikslais ir jų sprendimo būdais. Be to, jų metu apskritai mažai domètasi sportininkų neigiamo elgesio raiška. Galima daryti prielaidą, kad taip nutinka dèl tyrimo instrumentu stokos. Todėl kitų mokslininkų sukurtų patikimu ir validžių tyrimo instrumentu adaptavimas yra aktualus tiek skatinant tokius tyrimus, tiek tyrimo duomenų sklaidą.

Akcentuojant sportininkų elgesio sportinèje veikloje tyrimų aktualumą ir jų problematiškumą atkreiptinas demesys ị sportininkų vertybines orientacijas. Vertybių vaidmuo žmogaus veiksmams ir aplinkos suvokimui yra seniai žinomas (Rokeach, 1973). Vertybės parodo, kas individui ar grupei svarbu. Jos veikia kaip motyvuojantis veiksnys, suteikiantis veiksmams krypti ir intensyvumą, tarnauja tarsi standartai vertinant elgesi. Vertybiu sistema formuojasi asmeninès patirties metu ir internalizuojant individui svarbioje grupeje dominuojančias vertybes (Schwartz, 1994). Taigi vertybès veikia mūsu sprendimus tam tikromis situacijomis. Reikia pažymèti, kad sportuojančiu vaiku ir jaunimo vertybinès orientacijos nemažai tirtos ir Lietuvoje (Puniškienè, Laskienè, 2006; Malinauskas, 2008 ir kt.). Šiu tyrimų metu dažnai naudojama M. Rokeach vertybiu skalè. Manytume, ji tinkama norint palyginti skirtingu grupių vertybines orientacijas, tačiau galima abejoti jos taikymo tikslingumu, aiškinantis sportininkų vertybes sportineje veikloje. Todèl vertas dèmesio Jaunimo vertybiu sportineje veikloje klausimynas (Youth Sport Values Questionnaire - Lee et al., 2008), skirtas nustatyti, kokios vertybès sportininkams yra svarbios sportineje veikloje. Jame išskiriamos moralinių, gebejjimu ugdymo ir statuso vertybiu grupès. Šio klausimyno adaptavimas lietuviams yra aktualus analizuojant ne tik vertybes, svarbias sportuojantiems vaikams ir jaunimui, bet ir ju sąsajas su prosocialaus bei antisocialaus elgesio raiška.

Išsakyti teiginiai apie sportininkų elgesio sportinèje veikloje tyrimu problematiką ir nauju tyrimo instrumentų mokslineje spaudoje pristatymas paskatino adaptuoti minètus tyrimo instrumentus (gavus autoriu leidimus) lietuviams. Tyrimo tikslas - aprašyti prosocialaus bei antisocialaus elgesio ir jaunimo vertybių sportinèje veikloje 
instrumentų adaptavimo etapus, jų tinkamumą ivertinant bandomuoju tyrimu.

\section{TYRIMO METODIKA}

Norint adaptuoti du tyrimo instrumentus lietuviams ir patikrinti jų patikimumą bei validumą tyrimas vykdytas keturiais etapais.

Per pirmą etapą buvo atliekamas Prosocialaus ir antisocialaus elgesio sportinèje veikloje skalès bei Jaunimo vertybiu sportinejje veikloje klausimyno vertimas. Pažymètina, kad nors ir nèra griežtai nusistovejusių vieningų ir absoliučiai teisingų instrumento pritaikymo taisyklių (Riklikienè, 2007), kiekvienas tyrèjas turi pagrịsti adaptavimo logiką. Mokslineje literatūroje nurodoma, kad instrumento vertimo strategija turétu atitikti tyrimo, kurio metu instrumentas bus naudojamas, tikslą: ar ketinama atrasti naujus fenomenus, požymius, savybes kitoje kultūroje (vykdomasis tyrimas), ar siekiama lyginti jau žinomus skirtingų kultūrų ypatumus (palyginamasis tyrimas). Pirmuoju atveju originalaus instrumento turinio ir struktūros išlaikymas tampa esmine užduotimi, antruoju — būtinas tinkamas instrumento prasmès perkèlimas į kitą kultūrą (Jones et al., 2001 - cit. iš Riklikienè, 2007). Atliktu tyrimu siekème antro tikslo, todèl esmine užduotimi buvo originalo prasmès perkèlimas. Pirmiausia du anglų kalbos specialistai skalès ir klausimyno teiginius išverte i lietuvių kalbą. Paskui šiuos du vertimus ivvertino trečias anglų kalbos specialistas ir pateikè savo siūlymus. Pagal jo pastabas buvo kai kas pataisyta. Tada abiejų instrumentų išversti variantai įvertinti mokslininko, kurio tyrimų sritis susijusi su tais klausimais. Nors rekomenduojamas atgalinis vertimas, tačiau neatmetant jo naudingumo kartais tai tiesiog nebūtina daryti (Riklikienè, 2007). Mes atgalinio vertimo netaikème, tik bandomuoju tyrimu ivertinome vertima. Adaptuojamu tyrimo instrumentu autoriai taip pat neišreišké pageidavimo pamatyti atgalinio vertimo versijos.

Per antrą etapą buvo atliktas bandomasis tyrimas apklausiant 170 (32 merginas ir 138 vaikinus) sportuojančių studentų. Studentai buvo parinkti patogiuoju būdu iš ịvairių Lietuvos universitetú. Parenkant studentus buvo keliama sąlyga, kad jie būtu dalyvavę šalies čempionate, t. y. orientuotasi i aukštesnio meistriškumo sportininkus. Todèl tarp apklaustujų 85,3\% nurodè, kad yra dalyvavę šalies čempionate $(88,4 \%$ vaikinu ir $71,9 \%$ merginų), $47,6 \%$ yra tapę šalies prizininkais $(42,0 \%$ vaikinu ir $71,9 \%$ merginu), $15,9 \%$ dalyvavę ir Europos čempionate (12,3\% vaikinu ir $31,3 \%$ merginu), o
$1,8 \%$ - pasaulio čempionate ar olimpinèse žaidynèse (vienas vaikinas ir 2 merginos). Apklausti studentai pagal sporto šakas pasiskirste taip: 86 kultivuoja krepšini, 40 - futbolą, 23 - rankini, 14 - tinklinị, 4 - regbi ir 3 - žolès riedulị. Studentai pasirinktą sporto šaką kultivavo vidutiniškai 10 metų.

Pirmiausia studentai, vertindami 20 Prosocialaus ir antisocialaus elgesio sportineje veikloje skalès teiginių, turèjo atsakyti, kaip dažnai per praejjusius metus jiems teko atlikti teiginiuose nurodytus veiksmus, pasirenkant vieną iš penkių atsakymo variantų nuo niekada (1) iki labai dažnai (5). Tada jiems pateiktas Jaunimo vertybiu sportineje veikloje klausimynas. Vertindami trylika teiginiu turejjo pasirinkti vieną iš septyniu atsakymo variantu: nuo ypač svarbu man (5) iki tai prieštarauja tam, kuo aš tikiu (-1). Taip pat klausimyne buvo keletas klausimu apie pačius tiriamuosius: sporto šaką, sportinę patirti, sportinius laimejjimus ir lyti.

Per trečią etapą taikant tiriamosios faktorinès analizès matematini modeli buvo siekiama išskirti faktorius (skales) ir įvertinti, kaip jie atitinka instrumentu autoriu išskirtuosius.

Per ketvirtą etapą išskyrus instrumentus sudarančius faktorius (skales), patikrintas ju patikimumas skaičiuojant vidinio suderinamumo (Kronbacho alfa) reikšmes. Taip pat tikrintas instrumentų validumas. Kalbant apie instrumento validumą, esmine sąvoka paminètinas konstrukto validumas, t. y. visas instrumentas ar atskiros jo dalys matuoja teoriškai operacionalizuotą objektą ar tam tikrus jo kintamuosius. Tačiau dažnai būna sudètinga ji nustatyti, nes, pirma, sudètinga objektą ar jo kintamuosius apibrèžti, ir, antra, ribotos ju empirinio patikrinimo galimybès (Sattler, Hoge, 2006). Todèl vertinant validumą tikrinama, ar analizès metu išskiriami faktoriai atitinka teoriškai apibrèžtus rodiklius, ar yra koreliacija tarp teoriškai artimų panašių rodiklių (konvergencijos validumas) ir, atvirkščiai, ar nèra koreliacijos tarp teoriškai skirtingų rodiklių (diskriminacijos validumas) (Sattler, Hoge, 2006).

Kadangi nekūrème naujų, o tikrinome tik adaptuotus instrumentus, tokių pačių prasminių faktoriu (skalių) išskyrimą galima vertinti kaip vieną iš instrumento validumo požymių. Vertinant adaptuotų instrumentų validumą taip pat tikrintos kelios prielaidos (skaičiuojant Pirsono koreliacijos koeficientus). Pirmoji teigè, kad bus teigiamas ryšys tarp sportininku prosocialaus elgesio su komanda ir varžovais, o antisocialus elgesys su komanda - su 
antisocialiu elgesiu su varžovais. Antroji numatè, kad moralinès vertybès teigiamai koreliuos su gebèjimų sportinejje veikloje ugdymo vertybėmis, o šios su statuso vertybėmis. Pažymètina, kad abu instrumentai panaudoti tikrinant jų konkurencijos validumą. Tikrinta prielaida, kad antruoju instrumentu nustatytos moralinès vertybès sportinèje veikloje bus teigiamai susijusios su sportininku prosocialiu elgesiu ir neigiamai su jų antisocialiu elgesiu.

Tikrinant adaptuojamus instrumentus taip pat skaičiuoti šie aprašomosios statistikos rodikliai: aritmetinis vidurkis, standartinis nuokrypis.

\section{REZULTATAI}

Analizuojant prosocialaus ir antisocialaus elgesio sportineje veikloje rezultatus pirmiausia buvo siekiama išskirti faktorius taikant tiriamosios faktorinès analizès matematini modelị. Nustatyta, kad skalès duomenys faktorių analizei tinka vidutiniškai $-\mathrm{KMO}=0,78$; Bartlett sferiškumo testo $\mathrm{p}<0,001$. Taikyta pagrindinių komponenčiu analizè ir ortogonalusis Varimax sukimas. Duomenys apie išskirtų faktorių tikrines reikšmes ir paaiškinamos dispersijos dali pateikti 1 lentelèje. Buvo išskirti keturi faktoriai, kurie paaiškina 59,24\% visos dispersijos. Mūsų išskirti faktoriai ir juos sudarantys teiginiai visiškai sutapo su instrumento autorių išskirtaisiais. Kaip ir originale, Antisocialaus elgesio su varžovais skalę sudaro daugiausia teiginiu, o Prosocialaus elgesio su varžovais skalę - mažiausiai teiginių. Visų skalių vidinis suderinamumo balas yra tinkamas (nuo 0,79 iki $0,85)$. Nustatytas silpnas ryšys tarp sportininku prosocialaus elgesio su komanda ir varžovais $(\mathrm{r}=$ $0,29 ; p<0,01)$. Pastebėtas ryšys tarp sportininku antisocialaus elgesio su komandos draugais ir ju elgesio su varžovais $(r=0,31 ; p<0,01)$.

\begin{abstract}
1 lentelè. Prosocialau ir antisocialaus elgesio sportinèje veikloje išskirti faktoriai, juos paaiškinančios dispersijos dalis, aprašomosios statistikos bei vidinio suderinamumo duomenys (n= 170)
\end{abstract}

Pastaba. AEV - antiso cialus elgesys su varžovais; AEK - antisocialus elgesys su komanda PEK - prosocialus elgesys su komanda; PEV prosocialus elgesys su varžovais.

\begin{tabular}{|c|c|c|c|c|}
\hline \multirow{2}{*}{ Elgesio atvejai } & \multicolumn{4}{|c|}{ Faktoriai } \\
\hline & AEV & AEK & PEK & PEV \\
\hline 18. Tyčia pažeidète sportinės kovos taisykles & 0,77 & & & \\
\hline 16. Tyčia erzinote bandydami išvesti iš kantrybès varžovą & 0,72 & & & \\
\hline 14. Provokavote varžovą atlikti draudžiamus veiksmus & 0,68 & & & \\
\hline 15. Tyčia prasižengète prieš varžovą & 0,68 & & & \\
\hline 19. Fiziškai gąsdinote, bandydami įbauginti varžovą & 0,67 & & & \\
\hline 17. Atkeršijote varžovui už jo šiurkščią pražangą tuo pačiu & 0,66 & & & \\
\hline 13. Bandète sužeisti varžovą & 0,64 & & & \\
\hline 20. Kritikavote varžovą & 0,56 & & & \\
\hline 9. Keikète komandos narị / narius & & 0,81 & & \\
\hline 11. Kritikavote komandos narị / narius & & 0,78 & & \\
\hline 10. Ginčijotès su komandos nariu / nariais & & 0,76 & & \\
\hline 8. Užgauliojote komandos narį / narius & & 0,74 & & \\
\hline $\begin{array}{l}\text { Rodète nepasitenkinimą prastu komandos nario / narių } \\
\text { žaidimu }\end{array}$ & & 0,65 & & \\
\hline 1. Skatinote, drąsinote komandos narị / narius & & & 0,86 & \\
\hline 3. Teigiamai atsiliepète apie komandos narị / narius & & & 0,83 & \\
\hline 4. Patarète komandos nariui / nariams & & & 0,80 & \\
\hline 2. Pasveikinote komandos narị / narius už gerą žaidimą & & & 0,76 & \\
\hline 5. Padèjote susižeidusiam varžovui & & & & 0,86 \\
\hline 6. Paprašète sustabdyti sportinę kovą varžovui susižeidus & & & & 0,80 \\
\hline 7. Padèjote susižeidusiam varžovui & & & & 0,78 \\
\hline Paaiškinamos dispersijos kumuliatyvinis \% & 18,99 & 33,80 & 48,28 & 59,24 \\
\hline Vidurkis & 2,24 & 2,25 & 4,11 & 2,98 \\
\hline Standartinis nuokrypis & 0,68 & 0,65 & 0,67 & 0,87 \\
\hline Kronbacho alfa koeficientas & 0,85 & 0,83 & 0,84 & 0,79 \\
\hline
\end{tabular}




\begin{tabular}{|c|c|c|c|c|c|}
\hline \multirow{2}{*}{\multicolumn{2}{|c|}{ Elgesio atvejai }} & \multicolumn{3}{|c|}{ Faktoriai } & \multirow{19}{*}{$\begin{array}{l}2 \text { lentelè. Jaunimo vertybių } \\
\text { sportinèje veikloje išskirti } \\
\text { faktoriai, juos paaškinan- } \\
\text { čios dispersijos dalis, aprašo- } \\
\text { mosios statistikos ir vidinio } \\
\text { suderinamumo duomenys } \\
(\mathrm{n}=170)\end{array}$} \\
\hline & & GUV & MV & SY & \\
\hline 9. & Man svarbu tobulinti savo sportinį meistriškumą & 0.84 & & & \\
\hline 8 . & $\begin{array}{l}\text { Man svarbu iškelti sau tikslus, kurių noriu pasiekti } \\
\text { sportuodamas }\end{array}$ & 0.79 & & & \\
\hline 6. & Aš siekiu tapti geru sportininku & 0.77 & & & \\
\hline 7. & Aš siekiu sportuodamas atskleisti savo gebèjimus & 0.63 & & & \\
\hline 5 . & Sportuojant man svarbu būti sąžiningam & & 0.80 & & \\
\hline 3. & Aš siekiu padèti kitiems, kai jiems to reikia & & 0.79 & & \\
\hline 4. & Sportuodamas visada stengiuosi laikytis taisyklių & & 0.79 & & \\
\hline 2. & $\begin{array}{l}\text { Man svarbu sportuojant garbingai varžytis, } \\
\text { rungtyniauti }\end{array}$ & & 0.58 & & \\
\hline 1. & Sportuodamas aš sutinku tai daryti, kas man liepiama & & 0,34 & 0,31 & \\
\hline 13. & Man svarbu gerai atrodyti & & & 0.79 & \\
\hline 11. & Aš siekiu būti grupès lyderiu & & & 0.75 & \\
\hline 12. & Man svarbu laimèti ar nugalèti & & & 0.65 & \\
\hline \multirow[t]{5}{*}{10.} & Aš siekiu būti geresnis už kitus & & & 0.64 & \\
\hline & Paaiškinamos dispersijos kumuliatyvinis \% & 23,24 & 43,69 & 63,85 & \\
\hline & Vidurkis & 4,14 & 3,65 & 3,53 & \\
\hline & Standartinis nuokrypis & 0,92 & 0,83 & 1,15 & \\
\hline & Kronbacho alfa koeficientas & 0,85 & 0,70 & 0,80 & \\
\hline
\end{tabular}

Jaunimo vertybių sportineje veikloje klausimyno rezultatai faktoriu analizei tinka $-\mathrm{KMO}=$ 0,86 ; Bartlett sferiškumo testo $\mathrm{p}<0,001$. Duomenys apie išskirtų faktoriu tikrines reikšmes ir paaiškinamos dispersijos dali pateikti 2 lentelejje. Visi teiginiai (išskyrus vieną) sudaro tris faktorius, paaiškinančius $63,85 \%$ visos dispersijos, kurie sutampa su instrumento autorių išskirtaisiais. Vieno lentelèje nenurodyto teiginio Sportuodamas aš sutinku tai daryti, kas man liepiama reikšmè mažesnè negu 0,40 ir jis patenka i du faktorius. Kadangi originale šis teiginys priskirtas moralinėms vertybėms, mes jo nepašalinome iš skalès, bet priskyrème moralinių vertybių skalei. Visu trijų vertybiu skaliu vidinis suderinamumas yra geras (nuo 0,70 iki 0,85). Nustatytas vidutinio stiprumo koreliacinis ryšys tarp gebejjimų ugdymo ir moraliniu vertybiu $(r=0,47 ; p<0,01)$ bei tarp gebėjimų ugdymo vertybiu ir statuso vertybių $(r=$ $0,50 ; \mathrm{p}<0,01)$.

Tikrinant keltą prielaidą apie vertybiu sportinèje veikloje sąsajas su sportininku prosocialiu elgesiu skaičiuoti koreliaciniai ryšiai tarp atskiru vertybių grupių ir elgesio (žr. pav.). Mažesni negu silpni koreliaciniai ryšiai paveiksle nenurodyti. Nustatytas silpnas ryšys tarp moralinių vertybiu ir prosocialaus elgesio tiek su komandos draugais $(\mathrm{r}=0,34 ; \mathrm{p}<0,01)$, tiek su varžovais $(\mathrm{r}=0,30 ; \mathrm{p}<$
$0,01)$ bei neigiamas ryšys su antisocialiu sportininku elgesiu su varžovais $(r=-0,29 ; p<0,01)$. Atitinkamai teigiamas ryšys pastebimas tarp gebejjimu sportinejje veikloje ugdymo vertybių ir sportininku prosocialaus elgesio su komandos draugais $(\mathrm{r}=$ $0,35 ; \mathrm{p}<0,01)$. Paminètinas silpnas ryšys tarp sportininku prosocialaus ir antisocialaus elgesio su varžovais $(\mathrm{r}=0,20 ; \mathrm{p}<0,05)$. Atskirai analizuojant duomenis merginu ir vaikinų grupèse nustatytos panašios tendencijos, tačiau paminètini ir kai kurie skirtumai. Vaikinu grupejje išlieka panašūs koreliaciniai ryšiai, fiksuoti tarp visu sportuojančiuju. Tuo tarpu merginu grupejje nenustatytas koreliacinis ryšys tarp moralinių ir statuso vertybių sportinejje veikloje. Merginų grupejje nustatytas stipresnis neigiamas ryšys tarp moralinių sporto vertybių ir negarbingo sportininku elgesio su varžovais $(\mathrm{r}=-0,51 ; \mathrm{p}<0,01)$. Atitinkamai vaikinu grupeje šis ryšys silpnesnis $(r=-0,26 ; \mathrm{p}<0,01)$. Tik merginu grupeje nustatytas silpnas neigiamas ryšys tarp moralinių vertybiu sportinejje veikloje ir negarbingo elgesio su komandos draugais $(\mathrm{r}=$ $-0,31 ; p<0,05)$. Teigiamas ryšys aptiktas ne tik tarp gebejjimų ugdymo vertybių sportinèje veikloje ir prosocialaus elgesio su komandos draugais, bet ir tarp minètu vertybiu bei prosocialaus elgesio su varžovais $(\mathrm{r}=0,38 ; \mathrm{p}<0,05)$. Tai nebūdinga vaikinu grupei. Stipresnis ryšys nustatytas tarp 
Pav. Sąsajų tarp vertybių ir elgesio sportinèje veikloje koreliacinis modelis
Pastaba. * ${ }^{*} \mathrm{p}, 0,05, * *-\mathrm{p}, 0,001$.

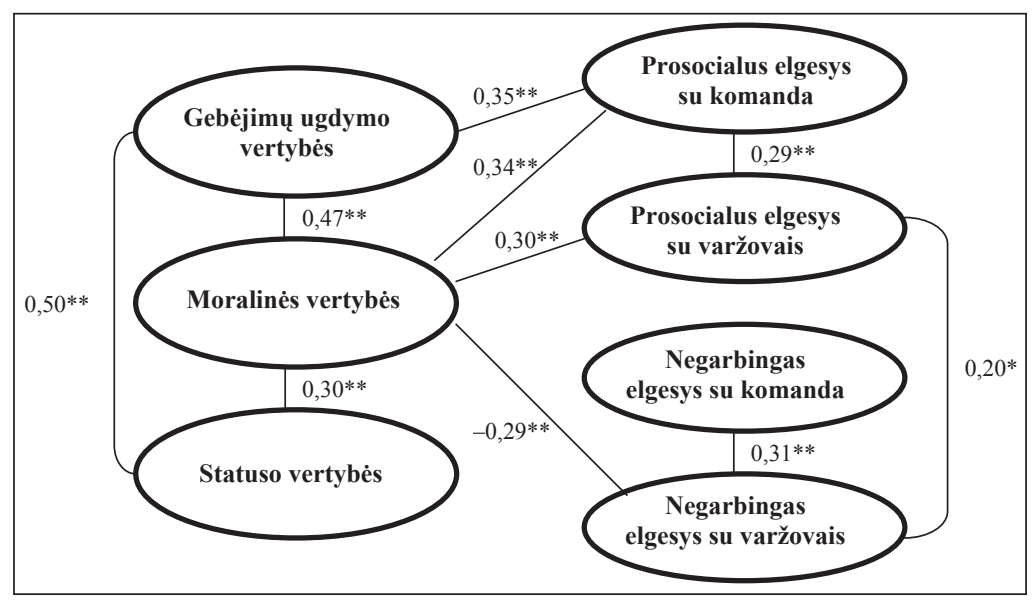

telio formuluote suprantama nevienareikšmiškai, t. y. aklas paklusimas nebūtinai gali būti susijęs su moraliu elgesiu. Paminètini ir kultūriniai bei tiriamuju amžiaus skirtumai suvokiant jo prasmę. Todèl tolesnių tyrimų metu taikant šį klausimyną, ypač tiriant vaikus, ir analizuojant rezultatus rekomenduotina dar kartą atlikti teiginiu faktoriu analizę. Reikia pasakyti, kad dèl minètų problemų adaptuojant klausimyną nebuvo galimybès konsultuotis su jo pagrindiniu autoriumi, o bendraautoriai manydami, kad jų indèlis kuriant ji per menkas, neišreiškè noro nuodugniau diskutuoti.

Bandomojo tyrimo metu nustatyti vidutinio stiprumo ryšiai tarp gebejjimų ugdymo ir moralinių bei statuso vertybių, kartu ir silpnas ryšys tarp moraliniu bei statuso vertybių. Šie koreliaciniai ryšiai sutampa su klausimyno autoriu pateiktais, kurie nurodo stipresni ryši tarp gebejjimų ugdymo ir moraliniu vertybių. Vertinant klausimyno patikimumą nustatytas tinkamas vertybiu grupių vidinis suderinamumas, kuris vertinant gebejjimų ugdymo vertybes buvo geresnis, o moralines - truputi blogesnis nei nurodytas autoriu.

Vertinant adaptuojamų tyrimo instrumentų validumą atlikta faktorių analizė ir tikrintas išskirtų faktoriu sutapimas su originale nurodytais, taip pat tikrintos sportininkų vertybių ir elgesio sportinejje veikloje sąsaju prielaidos. Nustatyta, kad moraliniu vertybių sportinejje veikloje duomenys patikimai teigiamai koreliuoja su sportininkų prosocialiu elgesiu tiek su komandos draugais, tiek su varžovais ir neigiamai su jų antisocialiu elgesiu su varžovais. Patikima teigiama koreliacija aptikta tarp gebejimų ugdymo vertybių sportinėje veikloje ir sportininku prosocialaus elgesio su komandos draugais. Kurdami vertybių sportinejje veikloje klausimyną, tyrejjai taip pat tikrino prielaida, kad moralinès ir gebejjimų ugdymo vertybès teigiamai koreliuoja su nuostatomis dél sportininku prosocialaus ir neigiamai su nuostatomis dèl antisociamoraliniu vertybiu grupe ir dèl to, kad jo vienin- 
laus elgesio sportinèje veikloje. Taip pat tikrinta prielaida, kad statuso vertybès teigiamai koreliuoja su nuostatomis dèl sportininku antisocialaus elgesio sportineje veikloje. Adaptuodami tyrimo instrumentus patikrinome analogiškas prielaidas, tik buvo vertinta vertybiu sportineje veikloje sąsajos ne su tiriamujų nuostatomis dèl sportininku elgesio, o su jų pačių elgesiu. Galbūt dèl to mūsų tyrimo metu nenustatytas koreliacinis ryšys tarp statuso vertybiu ir antisocialaus elgesio.

Apibendrinant tyrimą pasakytina, kad buvo adaptuoti du tyrimo instrumentai, kurie gali būti naudojami aiškinantis sportuojančių vaikų ir jaunimo vertybines orientacijas bei elgesi sportinèje veikloje. Atkreiptinas demesys, kad Prosocialaus ir antisocialaus elgesio sportinèje veikloje skalè skirta tirti ne nuostatoms dèl sportuojančiujų elgesio, o paties elgesio raiškai. Taip pat ji nenustato sportininkų garbingo ar negarbingo elgesio motyvų. Visgi gilinantis i elgesio motyvus ji gali būti naudojama su kitais tyrimo instrumentais, pavyzdžiui, aiškinantis laimejjimų motyvacijos sąsajas su prosocialaus ir antisocialaus elgesio raiška (Kavussanu, Boardley, 2009) ar veiksnius, lemiančius negarbingą elgesi
(Boardley, Kavussanu, 2008). Ši skalè taikytina tiriant komandines sporto šakas kultivuojančius asmenis, nes ji buvo kurta šių sporto šakų atstovams. Adaptuojant skalę taip pat remtasi komandines sporto šakas kultivuojančių studentų duomenimis. Norètume atkreipti démesi i tai, kad adaptuojant sportininkų elgesio sportinejje veikloje skalę dèmesys buvo sutelktas i ją sudarančius teiginius, bet ne i pati pavadinimą. Manytume, kad sąvoka prosocialus elgesys vartotina, tuo tarpu dèl antisocialaus elgesio galima diskutuoti. Kalbant apie Jaunimo vertybių sportinejje veikloje klausimyną pažymètina, kad jis taikytinas tik aiškinantis, ko siekia sportininkai sportuodami, tačiau abejotinas tiriant kitoje veikloje dalyvaujančių asmenu vertybes.

\section{IŠVADA}

Adaptuota Prosocialaus ir antisocialaus elgesio sportinèje veikloje skale bei Jaunimo vertybiu sportinèje veikloje klausimynas atitinka keliamus patikimumo ir validumo reikalavimus ir gali būti naudojami tiriant sportininkų elgesị ir vertybes sportinès veiklos požiūriu.

\section{LITERATŪRA}

Adaškevičienė, E., Budreikaitė, A. (2007). 12-14 metu mokinių požiūris i kilnų elgesį ir jo raiška sportinèje veikloje. Sporto mokslas, 3 (49), 72-77.

Arthur-Banning, S., Wells, M. S., Baker, B. L., Hegreness, R. (2009). Parents behaving badly? The relationship between the sportsmanship behaviors of adults and athletes in youth basketball games. Journal of Sport Behavior, 32 (1), 3-18.

Barr, J. J., Higgins-D'Alessandro, A. C. (2007). Adolescent empathy and prosocial behavior in the multidimensional context of school culture. The Journal of Genetic Psychology, 168 (3), 231-250.

Boardley, I. D., Kavussanu, M. (2008). The moral disengagement in sport scale - short. Journal of Sports Sciences, 26 (14), 1507-1517.

Bredemeier, B. J., Shields, D. L. (2001). Game reasoning and interactional morality. The Journal of Genetic Psychology, 147 (2), 257-275.

Bredemeier, B. J. L., Shields, D. L. (1998). Moral assessment in sport psychology. In J. L. Duda (Ed.), Advances in Sport and Exercise Psychology Measurement (pp. 257-276). Morgantown, WV: FIT Press.

Jones, C., McNamee, M. (2000). Moral reasoning, mora action, and the moral atmosphere of sport. Sport, Education and Society, 5 (2), 131-146.

Kavussanu, M., Boardley, I. D. (2009). The prosocial and antisocial behaviour in sport scale. Journal of Sport \& Exercise Psychology, 31, 97-117.

Kavussanu, M. (2006). Motivational predictors of prosocial and antisocial behaviour in football. Journal of Sports Sciences, 24 (6), 575-588.

Kavussanu, M., Ntoumanis, N. (2003). Participation in sport and moral functioning: Does ego orientation mediate their relationship? Journal of Sport and Exercise Psychology, 25, (4), 501-518.

Kavussanu, M., Roberts, G. (2001). Moral functioning in sport: An achievment goal perspective. Journal of Sport \& Exercise Psychology, 23, 37-54.

Lee, M. J., Whitehead, J., Ntoumanis, N., Hatzigeorgiadis, A. (2008). Relationships among values, achievement orientations, and attitudes in youth sport. Journal of Sport and Exercise Psychology, 30, 588-610.

Malinauskas, R. (2008). Sportuojančių Lietuvos kūno kultūros akademijos studentu vertybès. Sporto mokslas, 3 (53), 31-35.

Malinauskas, R., Šniras, Š. (2006). Ugdymo programos itaka sportuojančiu moksleiviu situaciniams socialiniams igūdžiams. Acta Paedagogica Vilnensia, 17, 111-121.

Puniškienė, R., Laskienè, S. (2006). Sportuojančiu paauglių vertybinių orientacijų, asmenybės savybių ir savigarbos ypatumai. Sporto mokslas, 4 (46), 48-54.

Riklikienè, O. (2007). Tradicinių metodologinių reikalavimų pritaikymas slaugos rezultatų klasifikacijos anketos adaptavimui lietuviu kalbai, kultūrai ir slaugos praktikai. Sveikatos mokslai, 5, 116-1172.

Rokeach, M. (1973). The Nature of Human Values. New York: The Free Press.

Sattler, J. M., Hoge, R. D. (2006). Assessment of Children. Behavioral, Social, and Clinical Foundations (5th Edition). San Diego: Jerome M. Sattler Publisher Inc.

Schwartz, S. H. (1994). Are there universal aspects in the structure and content of human values? The Journal of Social Issues, 50, 19-45.

Shields, D. L., LaVoi, N. M., Bredemeier, B. L., Power, F. C. (2007). Predictors of poor sportspersonship in 
youth sport: Personal attitudes and social influence. Journal of Sport and Exercise Psychology, 29 (6), 747-762.

Šukys, S. (2008). Būsimujų kūno kultūros specialistų nuostatu i dorovines vertybes sporte kaita studiju metais. Sporto mokslas, 4 (54), 21-27.

Šukys, S., Jankauskienė, J. (2008). Mokinių sportavimo ir fizinio aktyvumo laisvalaikiu sąsajos su psichosocialiniais, elgesio ir mokyklos veiksniais. Ugdymas. Küno kultūra. Sportas, 1 (68), 104-110.

VaezMousavi, S. M., Shojaei, M. (2005 a). Association between Coaches' Behaviors and Players' Aggressive and Assertive Actions. Iternational Journal of Applied Sport Sciences, 17 (2), 35-42.
VaezMousavi, S. M., Shojaei, M. (2005 b). Frequencies of aggressive behaviors in win, loss, and tie situations. Iternational Journal of Applied Sport Sciences, 17 (1), $42-50$.

Vallerand, R. J., Brière, N. M., Blanchard, C. M., Provencher, P. J. (1997). Development and validation of the multidimensional sportspersonship orientation scale. Journal of Sport and Exercise Psychology, 19, 197-206.

Vargas-Tonsing, T. M. (2009). An exploratory examination of the effects of coaches' pre-game speeches on athletes' perception of self-efficacy and emotion. Journal of Sport Behavior, 32 (1), 92-111.

\title{
ADAPTATION AND VALIDATION OF THE PROSOCIAL AND ANTISOCIAL BEHAVIOR IN SPORT SCALE AND YOUTH SPORT VALUES QUESTIONNAIRE FOR LITHUANIANS
}

\author{
Saulius Šukys \\ Lithuanian Academy of Physical Education, Kaunas, Lithuania
}

\begin{abstract}
M. Kavussanu and I. Boardley (2009) developed a scale for measuring prosocial and antisocial behavior in sport. M. Lee et al. (2008) developed a questionnaire for measuring youth values in sport. The aim of the present study was to adapt these research instruments in the Lithuanian language and to validate them. The adaptation process took four stages. In stage 1, linguistic and cross-cultural adaptation of the scale and questionnaire was made. In stage 2, 170 (32 female and 138 male) athletes recruited from Lithuanian universities completed the translated version of scale and questionnaire. In stage 3 , factorial analyze was performed in order to compare it with the original versions. In stage 4, investigations of factor structures, relationship between the scales, reliability, and construct validity of the adaptations were performed.

Factor analysis of the Prosocial and antisocial behavior in sport scale revealed a four factor solutions similar to those of the original scale version. Alpha coefficients showed good-to-very-good levels of internal consistency and were 0.85 for antisocial opponent behavior, 0.84 for prosocial teammate behavior, 0.83 for antisocial teammate behavior, and 0.79 for prosocial opponent behavior. Correlations between factors showed that prosocial behavior toward teammates was related positively to prosocial behavior toward opponents $(\mathrm{r}=$ $0.29 ; \mathrm{p}<0.01)$. Antisocial behavior toward opponents was positively related to antisocial behavior toward teammates $(r=0.31 ; p<0.01)$. Factor analysis of Youth values in sport questionnaire revealed three-factor solutions similar to those of the original version. Alpha coefficients showed good-to-very-good levels of internal consistency and were 0.85 for competence values, 0.80 for status values and 0.70 for moral values. Competence values were positively related to moral values $(\mathrm{r}=0.47 ; \mathrm{p}<0.01)$ and status values $(\mathrm{r}=0.50$; $\mathrm{p}<0.01)$.

As hypothesized, moral values positively related to prosocial behavior toward teammates $(\mathrm{r}=0.34 ; \mathrm{p}<$ $0.01)$ and opponents $(\mathrm{r}=0.30 ; \mathrm{p}<0.01)$ and negatively related to antisocial behavior toward opponents $(\mathrm{r}=$ $-0.29 ; \mathrm{p}<0.01)$.

In conclusion, the adapted scale and questionnaire can be used to measure behavior and values in sport.

Keywords: prosocial and antisocial behavior in sport, values in sport, adaptation of research tools, reliability and validity.

Gauta 2010 m. kovo 22 d.

Received on May 20, 2010

Priimta 2010 m. gegužès $31 \mathrm{~d}$.

Accepted on May 31, 2010

Saulius Šukys

Lietuvos kūno kultūros akademija

(Lithuanian Academy of Physical Education)

Sporto g. 6, LT-44221 Kaunas

Lietuva (Lithuania)

Tel +370 37302657

E-mailsml.saulius@gmail.com
\end{abstract}

